\title{
Hubungan antara Kadar 25-OH D3 dengan Derajat Fungsi Ginjal pada Pasien Lupus Sistemik Eritematosus
}

Aninditya Dwi Messaurina, Agung Triono, Retno Palupi Baroto, Cahya Dewi Satria, Sumadiono

Bagian Ilmu Kesehatan Anak Fakultas Kedokteran Kesehatan Masyarakat dan Keperawatan Universitas Gadjah Mada, Yogyakarta

Latar belakang. Defisiensi vitamin D banyak ditemukan pada anak lupus eritematosus sistemik (LSE) dibandingkan dengan anak normal. Berbagai penelitian membuktikan defisiensi vitamin D berkontribusi terhadap perkembangan chronic kidney disease. Belum ada penelitian hubungan vitamin $\mathrm{D}$ dengan derajat fungsi ginjal pada anak Lupus.

Tujuan. Mengetahui hubungan antara 25-hidroksivitamin D dengan derajat fungsi ginjal pada anak Lupus.

Metode. Menggunakan desain cross sectional dengan melibatkan 62 anak Lupus di bagian Ilmu Kesehatan Anak RSUP Dr. Sardjito yang telah mendapatkan protokol dari Januari 2014 sampai April 2018. Hubungan antara kadar serum 25-hidroksivitamin D dan derajat fungsi ginjal dianalisis menggunakan Independent T-test, sedangkan jenis kelamin, kalsium, steroid, dan aktivitas penyakit dengan uji chi-square. Defisiensi vitamin D didefinisikan konsentrasi 25 -hidroksivitamin $\mathrm{D}<20 \mathrm{ng} / \mathrm{ml}$, sedangkan gangguan ginjal didefinisikan GFR $<90 / \mathrm{ml} / \mathrm{mnt} / 1.73 \mathrm{~m}^{2}$.

Hasil. Sebagian besar subyek berjenis kelamin perempuan, 93,5\% vs 6,5\% dengan rerata usia 14,6 $\pm 3,1$ tahun, dan rerata skor Mex-SLEDAI 7,6 5,6. Secara keseluruhan 66\% subyek penelitian mengalami defisiensi vitamin D. Analisis dengan Independent T-tes menunjukkan rerata vitamin D yang mengalami gangguan ginjal 14,14 $\pm 4,9$ lebih rendah dibandingkan normal dengan rerata $19,43 \pm 10,3$ dengan perbedaan yang bermakna $\mathrm{p}=0,004$. Jenis kelamin, kalsium, steroid, dan aktivitas penyakit tidak berpengaruh signifikan terhadap derajat fungsi ginjal, $\mathrm{p}>0,05$.

Kesimpulan. Terdapat hubungan signifikan 25-hidroksivitamin D dengan derajat fungsi ginjal pada anak lupus. Sari Pediatri 2019;21(4):213-7

Kata kunci: vitamin D, fungsi ginjal, lupus sistemik eritematosus, anak

\section{The Association between 25-OH D3 and Degree of Renal Function in Children with Systemic Lupus Erythematosus}

\author{
Aninditya Dwi Messaurina, Agung Triono, Retno Palupi Baroto, Cahya Dewi Satria, Sumadiono
}

Background. Vitamin D deficiency is commonly found in children with Systemic Lupus Erythematosus compared to normal individual. Studies showed that vitamin D deficiency contributes to the progression of chronic kidney disease. The association between vitamin $\mathrm{D}$ and renal function in children with lupus has not been well defined.

Objective. Determine the association between 25-hydroxyvitamin and degree of renal function in children with Lupus.

Methods. Cross sectional study involving 62 pediatric lupus patients in the Department of Child Health, Sardjito Hospital who followed the treatment protocol from January 2014 to April 2018. The association between serum levels of 25-hydroxyvitamin D and renal function was analyzed using Independent T-test, whereas gender, calcium, steroids and disease activity using Chi-square test. Vitamin D deficiency was defined as concentration levels of 25 -hydroxyvitamin $\mathrm{D}<20 \mathrm{ng} / \mathrm{ml}$ whereas renal disturbance was defined as GFR $<90 / \mathrm{ml} / \mathrm{mnt} / 1.73 \mathrm{~m}^{2}$.

Result. Most of the subjects assigned for this study were girls, 93,5\% vs 6,5\% with mean of age 14,6 3 , 1 years old and Mex-SLEDAI score 7,6 $\pm 5,6$. In total, $66 \%$ of participants had vitamin D deficiency. Analysis with Independent T-test showed that the average vitamin D 14,14 \pm 4,9 was lower than normal with an average of 19,43 $\pm 10,3$ with a significant difference $\mathrm{p}=0,004$. Gender, calcium, steroids and disease activity had no significant effect on degree of renal function, $\mathrm{p}>0.05$.

Conclusion. There was a significant association between 25-hydroxyvitamin D and degree of renal function in pediatric lupus patients. Sari Pediatri 2019;21(4):213-7

Keywords: vitamin D, renal function, systemic lupus erythematosus, children

Alamat korespondensi: Aninditya Dwi Messaurina. Departemen Ilmu Kesehatan Anak, Fakultas Kedokteran Kesehatan Masyarakat dan Keperawatan, Universitas Gadjah Mada, Gedung Radiopoetro Lantai 3, Jl Farmako, Sekip, Yogyakarta 55281. Email: messaurina.ugm@gmail.com 
$\mathrm{P}$ enyakit lupus sistemik eritematosus (LSE) merupakan penyakit inflamasi autoimun kronis yang belum jelas penyebabnya, memiliki gambaran klinis yang luas serta tampilan perjalanan penyakit yang beragam. Insidensi LSE di Indonesia sekitar 1.250.000 penderita. ${ }^{1}$ Duapuluh persen kasus LSE terjadi pada anak yang berusia di atas usia 10 tahun, dengan dominasi jenis kelamin perempuan., ${ }^{2,3}$ Diagnosis LSE tidak mudah dan sering terlambat dikarenakan manifestasi klinis LSE sangat luas, meliputi keterlibatan kulit dan mukosa, sendi, darah, jantung, paru, ginjal, susunan saraf pusat (SSP) dan sistem imun. ${ }^{1}$ Diagnosis lupus ditegakkan dengan didapatkan minimal 4 dari 11 kriteria ACR atau 4 dari 17 kriteria Systemic Lupus International Collaborating Clinics (SLICC). 4,5

Perjalanan LSE bersifat episodik dan ditandai oleh fase remisi dan flare dan perlu adanya pemantauan aktivitas penyakit secara berkala dengan menggunakan Mex SLEDAI. ${ }^{4}$ Morbiditas dan mortalitas pasien LSE masih cukup tinggi. Berturut-turut survival rate LSE untuk 1-5 tahun, 5-10 tahun, 10-15 tahun, 15-20 tahun, dan 20 tahun adalah 93-97\%, 84-95\%, 70-85\%, 64-80\% dan $53-64 \%{ }^{1}$

Pasien LSE dianjurkan untuk menghindari paparan sinar matahari secara langsung yang merupakan penyebab tersering terjadinya flare. Sinar matahari adalah sumber utama dari vitamin D3 (cholecalsiferol), saat kulit terpapar dengan sinar ultraviolet B (UVB) sehingga pasien LSE berisiko mengalami defisiensi vitamin D3. Terapi medikamentosa yang diberikan meliputi steroid, khloroquin, kalsium, lisinopril dan vitamin D. ${ }^{1}$ Defisiensi vitamin D berkontribusi terhadap perkembangan chronic kidney disease. Namun, belum ada penelitian mengenai hubungan vitamin $\mathrm{D}$ dengan derajat fungsi ginjal pada pasien anak dengan LSE.

\section{Metode}

Penelitian ini merupakan penelitian analitik dengan desain cross sectional. Data penelitian diambil secara sekunder dari penelitian payung dengan judul status vitamin D pada pasien anak dengan LSE dari Januari
2014 sampai April 2018. Penelitian ini dilakukan di RSUP Dr Sardjito yang merupakan pusat rujukan DIY dan sekitarnya, Bagian Poli Anak Divisi AlergiImmunologi.

Sampel dipilih berdasarkan convenience sampling. Kriteria inklusi adalah anak yang telah terdiagnosis LSE saat usia kurang dari 18 tahun di RSUP Dr. Sardjito dan masih mendapatkan terapi sesuai protokol LSE, minimal sudah berjalan 12 minggu terapi. Kriteria eksklusi adalah pasien dengan sindrom metabolik, terdapat kelainan genetik atau bawaan yang berpengaruh terhadap metabolisme vitamin $\mathrm{D}$ dan ginjal. Besar sampel yang diperlukan adalah 62 orang. Data sekunder kadar vitamin D dan GFR subjek didapat dari penelitian payung. Penelitian ini telah memperoleh kelaikan etik dari Medical and Health Research Ethics Committee (MHREC) Fakultas Kedokteran Universitas Gadjah Mada, Yogyakarta. Data yang diambil tersebut dimasukkan ke dalam program perangkat lunak SPSS 20.0. Data dianalisis dengan Independent T-test dan uji chi-square. Tingkat kemaknaan dalam penelitian ini dinyatakan bila $\mathrm{p}<0,05$.

\section{Hasil}

Penelitian secara cross sectional dari data sekunder penelitian payung untuk mengetahui perbedaan status vitamin D terhadap fungsi ginjal pada pasien anak dengan LSE. Median umur pada pasien defisiensi vitamin $\mathrm{D}$ adalah 15 tahun dengan rentang 12-18 tahun dan pada vitamin $\mathrm{D}$ normal 14 tahun dengan rentang 10-18 tahun. Sebagian besar pasien kedua kelompok adalah perempuan (95,1\% dan 90,5\%), tetapi secara keseluruhan pasien LSE, baik yang mengalami defisiensi vitamin D maupun yang tidak, dominan perempuan dibandingkan laki-laki $(93,5 \%$ vs $6,5 \%)$.

Seluruh subyek penelitian tidak memiliki riwayat LSE saudara, sedangkan riwayat pada orangtua hanya didapatkan pada subyek dengan vitamin D normal, yaitu sebesar 9,5\%. Pada pasien yang mengalami defisiensi vitamin D lebih banyak menggunakan protokol lupus berat $(53,7 \%)$, sedangkan subyek dengan vitamin $\mathrm{D}$ normal lebih banyak menggunakan protokol tidak berat $(61,9 \%)$. Proteinuria ditemukan pada pasien baik dengan defisiensi vitamin $\mathrm{D}$ maupun vitamin $\mathrm{D}$ normal. Nilai $\mathrm{p}>0,05$ menunjukkan 
tidak ada perbedaan umur jenis kelamin, riwayat LSE saudara dan orang tua, jenis protokol, dan proteinuria antara vitamin $\mathrm{D}$ yang rendah dan normal. Heterogenitas sampel yang didapat tidak berbeda signifikan. Karakteristik subyek penelitian tertera pada Tabel 1 .

Analisis dengan uji Independent T-test menunjukkan rata-rata vitamin $\mathrm{D}$ yang mengalami gangguan ginjal $14,14 \pm 4,9$ lebih rendah dibandingkan pada normal dengan rata-rata $19,43 \pm 10,3$ dan perbedaan yang bermakna $(p=0,004)$. Obesitas, kalsium, steroid, aktivitas penyakit, dan jenis kelamin tidak ada perbedaan yang signifikan dengan gangguan fungsi ginjal $(p>0,05)$. Hal ini tertera pada Tabel 2 dan 3 .

Tabel 1. Karakteristik subjek penelitian

\begin{tabular}{|c|c|c|c|c|c|c|}
\hline \multirow{4}{*}{$\begin{array}{l}\text { Usia (tahun) } \\
\text { Jenis kelamin }\end{array}$} & \multicolumn{5}{|c|}{ Status vitamin D (\%) } & \multirow[t]{2}{*}{$\mathrm{p}$} \\
\hline & \multicolumn{3}{|c|}{ Defisiensi $(\mathrm{n}=41)$} & \multicolumn{2}{|c|}{ Normal $(\mathrm{n}=21)$} & \\
\hline & & \multicolumn{2}{|c|}{$15(12-18)$} & \multicolumn{2}{|c|}{$14(10-18)$} & 0,44 \\
\hline & Laki-laki & 2 & 4,9 & 2 & 9,5 & 0,59 \\
\hline Jenis kelamin & Perempuan & 39 & 95,1 & 19 & 90,5 & \\
\hline \multirow[t]{2}{*}{ Riwayat LSE saudara } & Ya & 0 & 0,0 & 0 & 0,0 & $\infty$ \\
\hline & Tidak & 41 & 100,0 & 21 & 100,0 & \\
\hline \multirow[t]{2}{*}{ Riwayat LSE orang tua } & Ya & 0 & 0,0 & 2 & 9,5 & 0,11 \\
\hline & Tidak & 41 & 100,0 & 19 & 90,5 & \\
\hline \multirow[t]{2}{*}{ Jenis protokol } & Lupus berat & 22 & 53,7 & 8 & 38,1 & 0,24 \\
\hline & Tidak berat & 19 & 46,3 & 13 & 61,9 & \\
\hline \multirow[t]{2}{*}{ Proteinuria } & $\leq+3$ & 39 & 95 & 20 & 95,0 & 0,51 \\
\hline & $>+3$ & 2 & 5,0 & 1 & 5,0 & \\
\hline
\end{tabular}

Tabel 2. Analisis terhadap gangguan ginjal

\begin{tabular}{lccccc}
\hline & Gangguan ginjal & $\mathrm{n}$ & Rerata & Standar deviasi & $\mathrm{p}$ \\
\hline Vitamin D $(\mathrm{ng} / \mathrm{mL})$ & Ya & 17 & 14,14 & 4,940 & \multirow{2}{*}{$0,004^{\mathrm{t}}$} \\
& Tidak & 45 & 19,43 & 10,310 & \\
\hline
\end{tabular}

${ }^{\mathrm{t}}$ Independent T-test

Tabel 3. Analisis terhadap gangguan ginjal

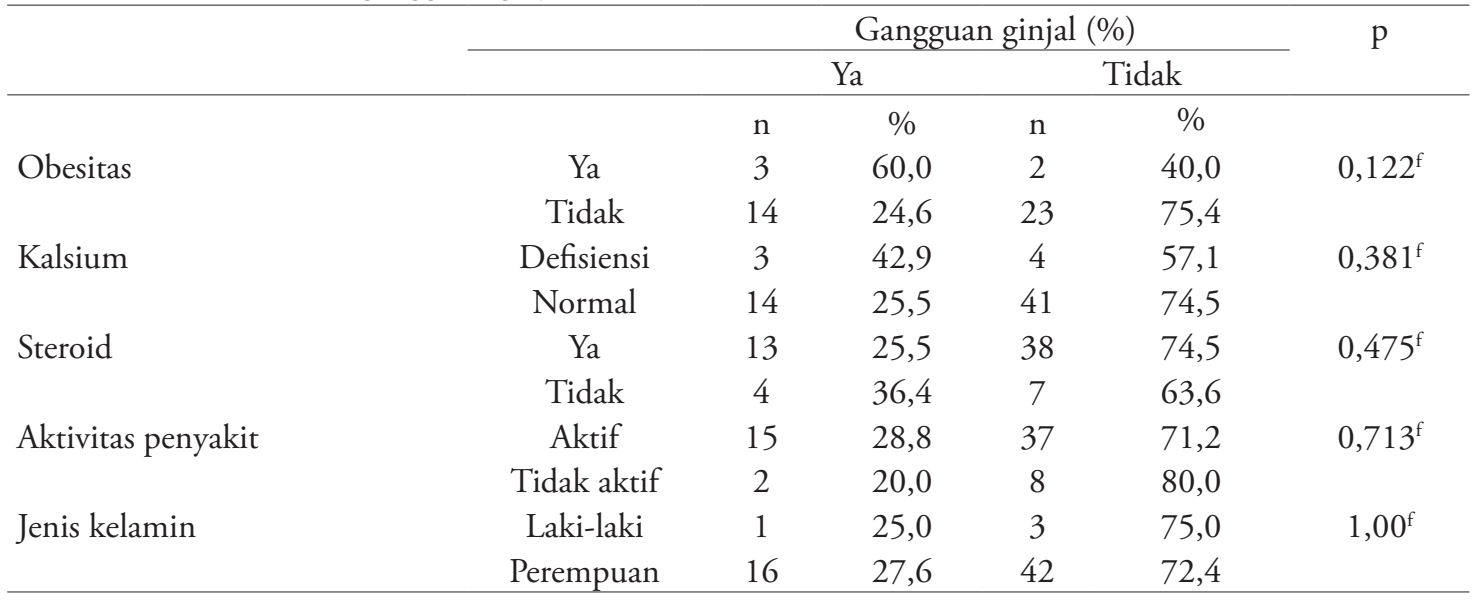

${ }^{\mathrm{c}}$ Uji Chi-square; ${ }^{\mathrm{f}} \mathrm{Uji}$ Fisher Exact 


\section{Pembahasan}

Pada penelitian ini, jumlah subyek penelitian didominasi anak perempuan dibandingkan anak lakilaki adalah $93,5 \%$ vs $6,5 \%$. Persentase berturut-turut subyek anak perempuan yang mengalami defisiensi vitamin $\mathrm{D}$ dan normal vitamin $\mathrm{D}$ adalah $95,1 \%$ dan 90,5\%. Dominasi ini sejalan dengan penelitian yang dilakukan Saleh $\mathrm{dkk}^{3}$ yang menunjukkan rasio perempuan : laki-laki adalah 3,6:1. Penelitian lain yang dilakukan di Columbia oleh Satirapoj $\mathrm{dkk}^{6}$ melaporkan bahwa $84 \%$ penderita LSE adalah anak perempuan dibanding laki-laki. Weckerle dan Niewold ${ }^{10}$, begitu pula dengan Schwartzman-Morris dan Putterman 11 melaporkan bahwa pada perempuan terdapat peningkatan IFN- $\alpha$. IFN- $\alpha$ pada pasien dengan LSE dan berkaitan dengan disease activity. IFN- $\alpha$ merupakan sitokin yang berhubungan dengan plasenta pada perempuan yang meningkatkan kerentanan LSE. Selain itu, faktor kromosom X pada perempuan, baik dari jumlah dan varian genetiknya meningkatkan risiko terjadinya LSE.

Dalam penelitian ini, ditunjukkan hubungan yang bermakna defisiensi vitamin D pasien anak LSE dengan derajat fungsi ginjal. Vitamin D merupakan salah satu vitamin yang larut dalam lemak, terdapat 5 bentuk vitamin $\mathrm{D}$, namun hanya 2 bentuk yang berperan penting pada manusia yaitu vitamin D2 (ergocalciferol) dan vitamin D3 (cholecalciferol). Vitamin D berasal dari makanan dan kulit dalam bentuk tidak aktif; sehingga diperlukan hidroksilasi oleh hepar dan ginjal untuk mengaktifkannya. Bila tubuh mendapat cukup sinar matahari, maka konsumsi vitamin D melalui makanan tidak dibutuhkan. Karena dapat disintesis di tubuh, vitamin $\mathrm{D}$ dapat dikatakan bukan vitamin, tapi suatu prohormon. $^{7}$

Sinar matahari adalah sumber utama dari vitamin D3 (cholecalsiferol), saat kulit terpapar dengan sinar ultraviolet B (UVB). Pada pasien LSE dianjurkan untuk menghindari paparan sinar matahari sehingga pasien LSE beresiko mengalami defisiensi vitamin D3. Sedangkan vitamin D2 (ergocalciferol) yang berasal dari sumber makanan hanya memiliki kontribusi kecil untuk status vitamin D secara keseluruhan. Sumber makanan yang memiliki kontribusi sebagai sumber vitamin D antaralain : susu, keju, telur, udang, kedelai, ikan, sereal, dan jamur. ${ }^{3}$

Cholecalciferol diubah menjadi calcifediol (25-hydroxycholecalciferol), sedangkan ergocalciferol diubah menjadi 25-hydroxyergocalciferol. Metabolit kedua vitamin $\mathrm{D}$ tersebut (25-hydroxyvitamin $D$ disebut atau 25(OH)D) diukur dalam serum untuk menentukan status vitamin D. Penurunan kadar 25$\mathrm{OH}$ vitamin $\mathrm{D}$ sangat lazim ditemukan pada pasien LSE dengan berbagai faktor risiko seperti kurangnya paparan sinar matahari sehingga ultraviolet $B$ (UVB) tidak dapat mensintesis vitamin D pada kulit, pemakaian glukokortikoid dalam jangka waktu lama, serta gangguan ginjal. Radiasi sinar matahari, khususnya UVB (280-315 nm) merupakan faktor resiko untuk kematian pasien LSE. Salah satu penelitian menyebutkan lebih dari $90 \%$ pasien dengan LSE yang terpapar radiasi UVB mengalami reaksi abnormal., ${ }^{3}$ Paparan ultraviolet $\mathrm{B}$ mengubah 7-dehydroxycholesterol akan difotokonversi menjadi provitamin D3, yang kemudian berikatan dengan vitamin-D binding protein. Vitamin D yang telah terikat dengan protein akan dibawa ke hati dan dihidrosilasi menjadi $25 \mathrm{OH}$ vitamin $\mathrm{D}$ yang dimetabolisme kembali menjadi 1,25 OH vitamin D. ${ }^{7}$

Hasil penelitian ini mendukung penelitian Melamed $^{8}$ yang melaporkan bahwa pada orang kulit hitam memiliki kadar vitamin D yang lebih rendah dibandingkan orang kulit putih dan meningkatkan risiko gangguan ginjal sebesar 2,6 kali. Penelitian AlSaleem dkk menyebutkan pasien yang kekurangan vitamin $\mathrm{D}$ memiliki kemungkinan dua kali lebih besar untuk terjadinya albuminuria selama periode lima tahun. Albuminuria merupakan indikasi awal kerusakan ginjal. ${ }^{9}$ Vitamin D juga berfungsi sebagai renoprotektif. Pada pasien LSE dengan gangguan ginjal terjadi peningkatan fibroblast growth factor 23 dan albuminuria akibat aktivitas renin angiotensin aldosteron sistem (RAAS). Aktivitas RAAS akan memengaruhi kalsitriol (1,25 dyhidroxyvitamin $\mathrm{D})$, fibroblast growth factor 23 melalui angiotensin II dengan cara menghambat reseptor angiotensin I melalui Nikotinmide Adenine Dinucleotide Phosphate Oxidase (NADPH Oksidase) dan stres oksidatif.?

\section{Kesimpulan}

Defisiensi vitamin D banyak ditemukan pada pasien anak dengan LSE dibandingkan dengan anak normal, hal ini disebabkan karena jarang melakukan aktifitas di luar rumah, penggunaan tabir surya serta kurangnya 
paparan sinar matahari. Adanya perbedaan yang signifikan defisiensi vitamin $\mathrm{D}$ terhadap gangguan fungsi ginjal sehingga penting melakukan pemantauan kadar vitamin D sebagai bagian dari pemantauan rutin pasien anak dengan LSE. Dengan hal tersebut, diharapkan dapat mencegah perkembangan gangguan ginjal pada pasien anak yang berisiko. Perlu penelitian lebih lanjut dengan desain yang bersifat longitudinal untuk mengetahui hubungan vitamin $\mathrm{D}$ dengan derajat fungsi ginjal.

\section{Daftar pustaka}

1. Kasjmir Y, Handono K, Wijaya L, Hamijoyo L, Albar Z, Kalim H, dkk. Rekomendasi Perhimpunan Reumatologi Indonesia untuk diagnosis dan pengelolaan lupus eritematosus sistemik. Jakarta: Perhimpunan Reumatologi Indonesia; 2011.

2. Levy DM, Kamphuis S. Systemic lupus erythematosus in children and adolescents [Internet]. Pediatr Clin North Am 2012; 59: 345-64. Didapat dari: http://linkinghub.elsevier.com/ retrieve/pii/s0031395512000089.

3. Saleh AM, Kurniati N, Syarif BH. Penilaian aktivitas penyakit lupus eritematosus sistemik dengan skor SLEDAI di departemen ilmu kesehatan anak RSCM. Sari Pediatri 2014; 16:292-8.

4. Aberle T, Bourn RL, Chen H, Roberts VC, Guthridge
JM, Bean K, dkk. Use of SLICC criteria in a large, diverse lupus registry enables SLE classification of a subset of ACR designated subjects with incomplete lupus. Lupus Sci Med 2017;4:1-8.

5. Sag P of the new $S$ classification criteria in childhood systemic lupus erythematosus: A multicentre study E, Tartaglione A, Batu ED, Ravelli A, Khalil SMA, Marks SD, dkk. Performance of the new SLICC classification criteria in childhood systemic lupus erythematosus: a multicentre study. Clin Exp Rheumatol 2014;32:440-4.

6. Satirapoj B, Wongchinsri J, Youngprang N, Laonapaporn B, Chitrada T, Lapkittichareonchai S, dkk. Predictors of renal involvement in patients with systemic lupus erythematosus. Asian Pac J Allergy Immunol [Internet]. 2007;25:17-25. Didapat dari: http://www.ncbi.nlm.nih.gov/ pubmed/17891918.

7. Singh A, Kamen DL. Potential benefits of vitamin D for patients with systemic lupus erythematosus. Dermatoendocrinol 2012;4:146-51.

8. Melamed ML, Astor B, Michos ED, Hostetter TH, Powe NR, Muntner P. 25-Hydroxyvitamin D Levels, Race, and the Progression of Kidney Disease. J Am Soc Nephrol 2009;20:2631-9.

9. AlSaleem A, AlE'ed A, AlSaghier A, Al-Mayouf SM. Vitamin $\mathrm{D}$ status in children with systemic lupus erythematosus and its association with clinical and laboratory parameters. Clin Rheumatol 2015;34:81-4. 